\title{
Simulation of Carbon Isotope Excursion Events at the Permian-Triassic Boundary Based on GEOCARB
}

https://doi.org/10.1515/geo-2018-0034

Received March 3, 2017; accepted April 4, 2018

\begin{abstract}
The biggest Phanerozoic mass extinctionoccurred at the Permian-Triassicboundary and resulted in the loss of about $95 \%$ or more of all marine species. For quite some time, many kinds of abnormal environmental events were adopted to explain the abnormal reduction of carbon isotope at the Permian-Triassic boundary, however there still has not been a unified opinion. In this paper, based on the carbon cycle balance model of the earth under a long-period scale, the contributions of possible cataclysm events at the Permian-Triassic boundary to the carbon isotope records in carbonates were quantitatively simulated. The results proved that a single event, such as volcanism, terrestrial ecosystem collapse or another factor, was not strong enough to lead to the negative bias of carbon isotope at the Permian-Triassic boundary. Even though the release of methane hydrate can result in a comparably large negative excursion of inorganic carbon, this explanation becomes unsuitable when both the shifting Permian-Triassic boundary and the fluctuation record of other inorganic carbon isotopes in the early Triassic as a whole are considered. Therefore, it is suggested that the dynamic equilibrium between inorganic carbon reserves and organic carbon reserves was possibly disturbed by a superimposed effect of multiple events.
\end{abstract}

Keywords: Permian-Triassic boundary; carbonate; carbon isotope; GEOCARB; Simulation

\section{Introduction}

From the Cambrian to modern times, the $\delta^{13} \mathrm{C}$ value of carbonate rocksmostly varies between $-2 \% \mathrm{ffl}$ and $6 \% \mathrm{ffl}[1]$. However, in some comparably short geological timescales,

\footnotetext{
Y. J. Zhong, Y. F. Lan, A. Q. Chen: Institute of Sedimentary Geology, Chengdu University of Technology, Chengdu 610059, China

*Corresponding Author: K. K. Huang: Institute of Sedimentary Geology, Chengdu University of Technology, Chengdu 610059, China, E-mail: 16913622@qq.com
}

major turning points of carbonate carbon isotopes took place, corresponding to critical stages of biological evolution and environmental change. At the end of the Permian, the most serious extinction event ever since there was life on earth occurred, which led to the complete disappearance of about $95 \%$ of species in the ocean. At the Permian-Triassic boundary, a significant and fast negative shift ( $<200 \mathrm{kyr})$ of the carbon isotope took place, during which the inorganic carbon isotope decreased from $+3 \sim+5 \% \mathrm{ffl}$ to $-1 \% \mathrm{ffl}$ with a mutation extent of $4 \% \mathrm{ffl} \sim 6 \% \mathrm{ffl}$. This abnormal carbon isotope event has been discovered in many areas, such as the Shangsi and Zhongliang mountain sections in Sichuan [2, 3], the Meishan section in Zhejiang [4], the Great Bank section in Nanpanjiang Basin of Guizhou [5], the South Alps [6], rock cores in the Carnic Alps of Austria [7], and elsewhere. Thus, it is indicated that this carbon isotope negative shift was a global event.

The abnormal fluctuation of the carbon isotope, as one of the most important ecological changes at the PermianTriassic boundary, has drawn extensive attention. This isotopic event is recorded worldwide and documents a change in the global carbon cycle [5]. It is also used as a complimentary marker for stratigraphic boundary delineation and comparisons [2-7]. However, geologists still have not reached a unified opinion about the inducement of this important carbon isotope change event.To sum up, the following possibilities have been proposed as causes for the documented changed in carbon isotope values: the oxidation of organic matter caused by a massive regression $[8,9]$, a volcanic eruption (Siberian trap events) [1014], an overturn event of oxygen-poor seawater [15], and the release of methane [16]. All of these geological events broke the original operation mechanism of the global carbon cycle and left traces of the carbon isotope in deposited carbonates.

It is worth mentioning that, among all these proposed causes of the carbon isotope excursion, some have acquired enough geological evidence while others remain controversial. Moreover, there still has not been a unified conclusion of which one is the dominant factor that caused the global carbon isotope negative anomaly event in the late Permian. Although all of these phenomena can ex- 
plain the variation tendency of the global carbon isotope at the Permian-Triassic boundary, there is still no mathematical proof of the influence strength. Hence, based on the exogenous global carbon cycle model GEOCARB described below, this paper quantitatively simulated the relationship between the variation of carbonate carbon isotope record at the Permian-Triassic boundary and possible cataclysm events.This was done in order to discuss the environmental change and related biological processes behind the abnormal evolution of the carbon isotope, and to seek more information about the great extinction of species.

\section{Description of GEOCARB}

Previous studies demonstrated that the carbon isotope keeps a mass balance during the global isotope cycling process [17-20]. Berner and Kothavala[21] established a global steady carbon cycle model (GEOCARB) in the scale of a million years via evaluating long-term carbon cycling. The most basic principle of this model is the following two equations:

$$
\begin{aligned}
& F_{W}^{c a r b}+F_{M}^{c a r b}+F_{W}^{o r g}+F_{M}^{o r g}=F_{B}^{c a r b}+F_{B}^{o r g} . \\
& \delta^{c a r b}\left(F_{W}^{c a r b}+F_{M}^{c a r b}\right)+\delta^{o r g}\left(F_{W}^{o r g}+F_{M}^{o r g}\right) \\
& =\delta_{B}^{c a r b} F_{B}^{c a r b}+\left(\delta_{B}^{c a r b}-\alpha_{B}^{o c}\right) F_{B}^{\text {org }}
\end{aligned}
$$

Where, $F$ is the flux of carbon; $\delta$ is $\delta^{13} \mathrm{C}(\% \mathrm{ffl})$; W stands for weathering; B stands for burial; $\mathrm{M}$ refers to earth internal actions (volcanism, metamorphism and rock-forming); carb represents carbonate; org stands for organic matter; and $\alpha \mathrm{Boc}$ is the isotope composition difference between organic matter and carbonate during burying. The left sides of the equations refer to the rate of releasing carbon to the earth surface system (Equation 1) and the composition of carbon isotope (Equation 2). The primary terms on the left side are the carbon released from carbonate and organic matter during weathering, and the carbon thermally decomposed during earth's endogenous actions. $\delta$ carb and $\delta$ org are the carbon isotope compositions of carbonate and organic matter after experiencing weathering and endogenous actions.

According to the GEOCARB model, under long-term stable conditions, the flux and carbon isotope of the input carbon and the output carbon maintain equilibrium. According to the description and data provided by Kump and Arthur [22], the global steady carbon cycle model in the scale of million years is summarized in Fig. 1, which demonstrates the fluxes and isotope compositions of carbon inputting and outputting via various ways into the atmosphere-ocean system. The carbon input into the atmosphere-ocean system from various geological events is considered as the carbon source in Fig. 1. These geological events contain carbon released through volcanism and metamorphism (mantle-derived $\mathrm{CO}_{2}$ ), carbon released from the oxidation of reduction carbon buried in ancient strata during tectonic uplift, and carbon dissolved from carbonate rocks and silicate rocks during weathering and brought by rivers into the ocean. At the same time, carbonate and organic matter leave the atmosphere-ocean system in the form of sediment burial, which is considered a carbon sink. During the evolution of the carbon cycle system, any sudden event will affect the carbon isotope composition and be recorded. Different events leave different traces on the carbon isotope record. Hence, the flux and isotope composition of carbon in each carbon reserve should be inspected to analyze the cause of the carbon isotope composition variation at the Permian-Triassic boundary.

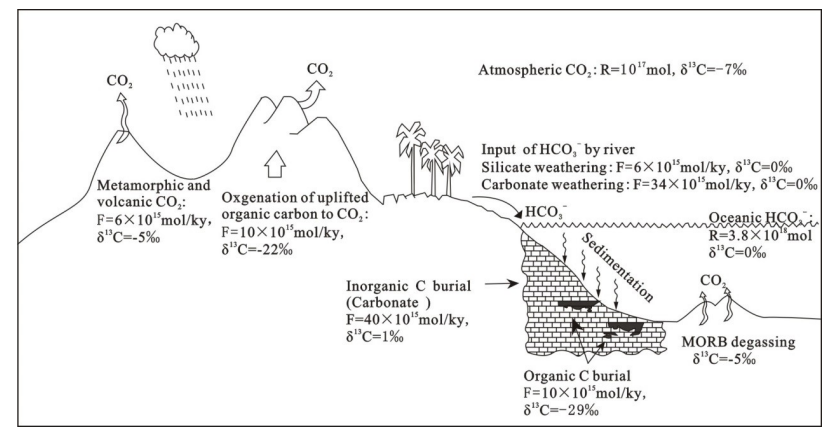

Figure 1: The global long-term carbon cycle diagram, demonstrating the reservoirs (R), flux $(\mathrm{F})$ and isotope composition of carbon, which can reasonably stand the average values in the Phanerozoic, modified after Kump and Arthur [22].

As displayed in Fig. 1, the fluxes and isotope compositions of different carbon reserves are as follows. The dissolved inorganic carbon (DIC) in the ocean has a total amount of about $3.8 \times 10^{18} \mathrm{~mol}$, with a carbon isotope content of $0 \% \mathrm{ffl}$. Since the residence time of DIC in the ocean $\left(\approx 10^{5}\right.$ years $)$ is far greater than the mixing time of seawater $\left(\approx 10^{3}\right.$ years), it is widely recognized that the carbon isotope compositions in global ocean waters are the same. The carbon storage in the air is 38 times lower than that in the ocean, and its value is $1 \times 10^{17} \mathrm{~mol}$ with a carbon isotope composition of $-7 \%$ ffl. In examining carbon sources, the carbon flux supplied by volcanism and metamorphism into the atmosphere-ocean system is about $6 \times 10^{15} \mathrm{~mol} / \mathrm{ky}$ and the isotope composition is around $-5 \% \mathrm{ffl}$. The carbon 
flux generated by the oxidation of original organic carbon during tectonic uplift is $10 \times 10^{15} \mathrm{~mol} / \mathrm{ky}$ with an isotope composition of $-22 \% \mathrm{ffl}$. The carbon flux produced by the weathering of carbonate and silicate is comparably high, with a value of $40 \times 10^{15} \mathrm{~mol} / \mathrm{ky}$ and isotope composition of $0 \% \mathrm{ffl}$. In examining carbon sinks, the sedimentation of carbonate takes away carbon with a flux of $40 \times 10^{15} \mathrm{~mol} / \mathrm{ky}$ and the related isotope composition is around $1 \% \mathrm{ffl}$. The autotroph carbon sequestration effect reduces carbon in the ocean system via organic carbon sedimentation, during which the carbon flux is about $10 \times 10^{15} \mathrm{~mol} / \mathrm{ky}$ and the isotope composition is around $-29 \% \mathrm{ffl}$.

\section{GEOCARB quantitative simulation method}

The carbon isotope fractionation effect involved in the carbon cycle process is displayed in Fig. 2 and summarized as follows:

1)The carbon isotope fractionation effect caused by biological carbon sequestration processes is the most significant, while the carbon isotope fractionation between living bodies and the sedimentation of organic matter is very limited (around $1 \% \mathrm{ffl}$ ). The combined carbon fractionation of these two processes is $29 \% \mathrm{ffl}$. 2)The oxidation of original organic carbon and the weathering dissolution of inorganic carbon leads to a very small carbon isotope fractionation. It is usually recognized that the carbon input into the ocean has the same carbon isotope composition with the carbon before oxidation and weathering, i.e., $-22 \% \mathrm{ffl}$ and $0 \%$ ffl, respectively. 3)During the sedimentation of carbonate minerals, the fractionation effect between watersoluble (heavy) carbonate ions $\left(\mathrm{CO}_{3}{ }^{2-} / \mathrm{HCO}_{3}{ }^{-}\right)$and $\mathrm{CaCO} 3$ is not significant, with a value of $1 \sim 2 \% \mathrm{ffl}[23]$. 4)The fractionation factor (mainly contributed by the ionization process) between $\mathrm{CO}_{2}$ gas and water-soluble (heavy) carbonate ions $\left(\mathrm{CO}_{3}{ }^{2-} / \mathrm{HCO}_{3}{ }^{-}\right)$in seawater is the function of temperature, i.e., it decreases with an increase in temperature. At $0^{\circ} \mathrm{C}$, the deviation caused by fractionation is $11.2 \% \mathrm{ffl}$, while it comes to $8.6 \% \mathrm{ffl}$ [24] when the temperature rises to $300^{\circ} \mathrm{C}$. Considering the relatively high environmental temperature in the early Triassic [25], the fractionation factor of this process is set as $7 \% \mathrm{ffl}$.

Since the carbon exchange among the three carbon reservoirs (biological carbon reservoir, atmospheric carbon reservoir, and ocean carbon reservoir) of the exogenous carbon cycle system as displayed in Fig. 1 took place within 2000 years, it can be assumed that the carbon quantity and carbon isotope composition of all three car- bon reservoirs are uniform, and the carbon exchange between them remains steady. Thus, the exogenous carbon cycle system can be considered as an integral whole [26], and the carbon isotope $\left(\delta_{E x}\right)$ changes with time $(\mathrm{t})$ by following:

$$
\frac{d \delta_{E x}}{d t}=\frac{F_{I n}}{M_{E x}}\left(\delta_{I n}-\delta_{E x}\right)-\frac{F_{O u t}}{M_{E x}}\left(\delta_{O u t}-\delta_{E x}\right)
$$

Where, $\mathrm{F}_{I n}, \mathrm{~F}_{O u t}, \delta_{I n}$, and $\delta_{E x}$ are the fluxes and car-

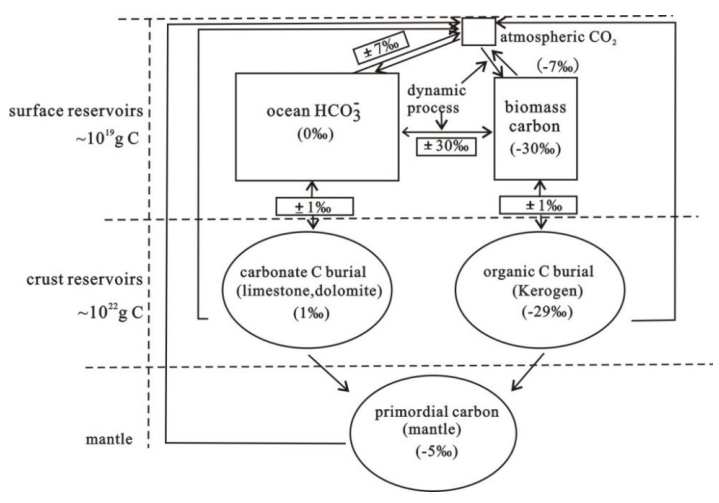

Figure 2: Schematic diagram of carbon isotope fractionation during carbon cycling among earth's surface, crust and mantle systems.

bon isotope values of carbon input into and output from the atmosphere-ocean system $\left(\delta\right.$ stands for $\delta^{13} \mathrm{C}$, hereafter the same), $\mathrm{M}_{E x}$ is the total carbon reserve in the exogenous carbon cycle system. Under the equilibrium state, the fluxes and isotope compositions of both the carbon source and carbon sink should be the same, that is, $\mathrm{d} \delta_{E x} / \mathrm{dt}=0$; $\mathrm{F}_{\text {In }}=\mathrm{F}_{\text {Out }} ; \delta_{\text {In }}=\delta_{\text {Out }}$. By substituting items involved in the GEOCARB model into Equation 3, the result is:

$$
\begin{gathered}
F_{\text {Wcarb }}+F_{\text {Mcarb }}+F_{\text {Worg }}+F_{\text {Morg }}=F_{\text {Bcarb }}+F_{\text {Borg }} . \\
\delta_{c a r b}\left(F_{\text {Wcarb }}+F_{\text {Mcarb }}\right)+\delta_{o r g}\left(F_{\text {Worg }}+F_{\text {Morg }}\right) \\
=\delta_{\text {Bcarb }} F_{\text {Bcarb }}+\left(\delta_{\text {Bcarb }}-\alpha_{o c}\right) F_{\text {Borg }} .
\end{gathered}
$$

Meanwhile, under non-equilibrium conditions, animbalance occurs between the carbon input into and output from the system by various geological and biological events contained in the GEOCARB model. Thus, the variation of total carbon quantity $\left(\mathrm{M}_{E x}\right)$ and carbon isotope in the exogenous carbon cycle system in the geological time scale $(\mathrm{t})$ can be expressed as:

$$
\frac{d M_{E x}}{d t}=F_{w c}+F_{w g}+F_{m}-\left(F_{b c}+F_{b g}\right)
$$

$$
\frac{d\left(\mathrm{M}_{\mathrm{Ex}} \times \delta_{\mathrm{Ex}}\right)}{d t}=
$$


$\left[\begin{array}{l}F_{W c a r b}\left(\delta_{W c a r b}-\delta_{\mathrm{Ex}}\right)+\mathrm{F}_{\mathrm{M}}\left(\delta_{\mathrm{M}}-\delta_{\mathrm{Ex}}\right)+\mathrm{F}_{\mathrm{Worg}}\left(\delta_{\mathrm{Worg}}-\delta_{\mathrm{Ex}}\right) \\ -\mathrm{F}_{\mathrm{Borg}}\left(\delta_{\mathrm{Borg}}-\delta_{\mathrm{Ex}}\right)-\mathrm{F}_{\mathrm{Bcarb}}\left(\delta_{\mathrm{Bcarb}}-\delta_{\mathrm{Ex}}\right)\end{array}\right]$

Where the carbon flux belonging to the mantle-derived carbon source is $\mathrm{F}_{M}$, and its carbon isotope composition is expressed as $\delta_{M}$. In addition, this equation contains the weathering process of inorganic carbon including silicate, by combining it with the weathering of carbonate. Hence, some parameters can be set, and the variation of carbon isotope can be evaluated according to the carbon flux and isotope composition of each carbon reserve.

\section{Parameter setting}

1) Based on studies of Milankovitch cycles and sedimentation rates, the duration of the negative excursion at the Permian-Triassic boundary is estimated to be 500,000 years [27-30]. 2)Time intervals of the other excursion events can be acquired via the strata thickness projection age method, based on the strata thickness in Fig. 6-5 and strata ages of key lines. 3) The $\delta^{13}$ Cvalue atthe end of the Permian is set as $4 \% \mathrm{ffl}$, which is the mid-value of the carbon isotope in the upper Permian part of the comprehensive carbon isotope curve [5]. 4) According to a reasonable estimated value of the stable atmospheric $\mathrm{PCO}_{2}$ provided by Berner and Kothavala [21] based on GEOCARB, the initial $\mathrm{PCO}_{2}$ is set as 1500 ppmv here. 5) The carbon isotope ratios of both inorganic carbon and organic carbon are changing in parallel in the marine carbonate sedimentary strata across the Permian-Triassic boundary interval [31]. Hence, it is assumed that the isotope composition difference is a constant value between organic matter and carbonate during burying in this study. 6) We also assume that abnormal geological events occur instantaneously and events that may reduce the isotope influencing effect are ignored. For example, during a volcanic eruption, the release of $\mathrm{CO}_{2}$ is considered, but the increase of carbonate rock dissolution and the improvement of carbonate compensation depth are neglected. 7) The carbon exchange between different carbon reserves takes place instantaneously, thus, the carbon isotope in the exogenous carbon cycle system changes in a similar way to that of the seawater carbon isotope. 8) As for geological time, climatic variations and tectonic events almost take place instantaneously. Hence, the intrinsic occurrence time of these events was not taken into account, and only the prolonged period of these events is changing the ancient environment.

\section{Simulation results and analysis}

If the seawater carbon isotope fluctuation around the Permian-Triassic boundary can be considered as a response to a certain extreme environmental event, the possible contribution of this event to the carbon isotope variation can be simulated by using the carbon cycle model constructed above.

\subsection{Volcanic activity}

The Permian-Triassic is a period with active volcanism, among which, the Siberian trap event is the strongest and largest in aerial extent. This event is widely recognized as the major cause of the negative excursion of carbon isotope at the Permian-Triassic boundary [10-12, 27]. The $\delta^{13} \mathrm{C}$ value of $\mathrm{CO}_{2}$ in volcanic gasses (including those pushed by marine basalt into the ocean) is about $-5 \% \mathrm{ffl}$, which can be considered as a constant in the geological time scale. One $\mathrm{km}^{3}$ of basalt can gush out $5 \times 10^{12} \mathrm{~g}$ C. Although the original volume of matter extruded by the trap rocks still cannot be precisely determined, Kamo et al. [10]suggested that the volume of available Siberian trap rock is $4 \times 10^{6} \mathrm{~km}^{3}$ and the original volume is thereby estimated to be $7 \times 10^{6} \mathrm{~km}^{3}$, based on studies on the Maymecha-Kotuy area of Russia. Therefore, the maximum quantity of carbon erupted in the Siberian trap rock event was $3.5 \times 10^{19} \mathrm{~g}$, which corresponds to about $3 \times 10^{18} \mathrm{~mol} \mathrm{C}$. The minimum quantity is $2 \times 10^{19} \mathrm{~g}$, around $1.7 \times 10^{18} \mathrm{~mol} \mathrm{C}$. Kamo et al. [10] conducted U-Pb age determination on perovskite and zircon in unbroken volcanic rock strata and found that the major eruption time of Siberian trap rock started around251.7 $\pm 0.4 \mathrm{Ma}$ and ended before $251.1 \pm 0.3 \mathrm{Ma}$, indicating an eruption period of $0.6 \mathrm{Myr}$. The results revealed that if the carbon ejected during volcanic activities releases gradually within $0.6 \mathrm{Myr}$, its influence on the carbonate carbon isotope is very limited with a reduction rate less than 1\%ffl (Fig. 3b). Even if the major eruption concentrates within a very short period, by assuming that $90 \%$ of carbon is released within $30 \mathrm{kyr}$ (Fig. 4a), its contribution to the negative excursion of carbonate $\delta^{13} \mathrm{C}$ is just $2.32 \% \mathrm{ffl}$ and $1.19 \% \mathrm{ffl}$, corresponding to the simulated maximum and minimum values, respectively (Fig. 4b).

In the lower Triassic marine carbonate successions we investigated, there are several layers of volcanogenic tuff. Thus, this indicates that volcanic activities were very frequent in the entirety of the early Triassic. However, the strength of these volcanic activities are far weaker than that of the Siberian volcanoes, and their direct contribu- 

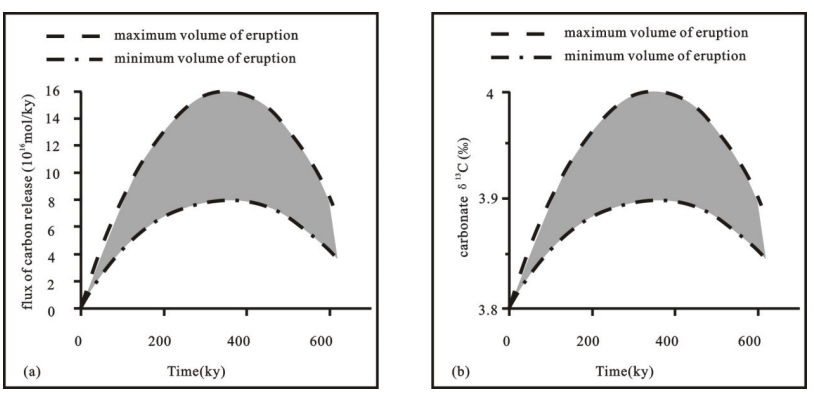

Figure 3: The figure shows the relationship between time and simulated carbon flux by progressively continuous volcanic eruption (a) and the relationship between time and the resulted $\delta^{13} \mathrm{C}$ values within 0.6 Ma.
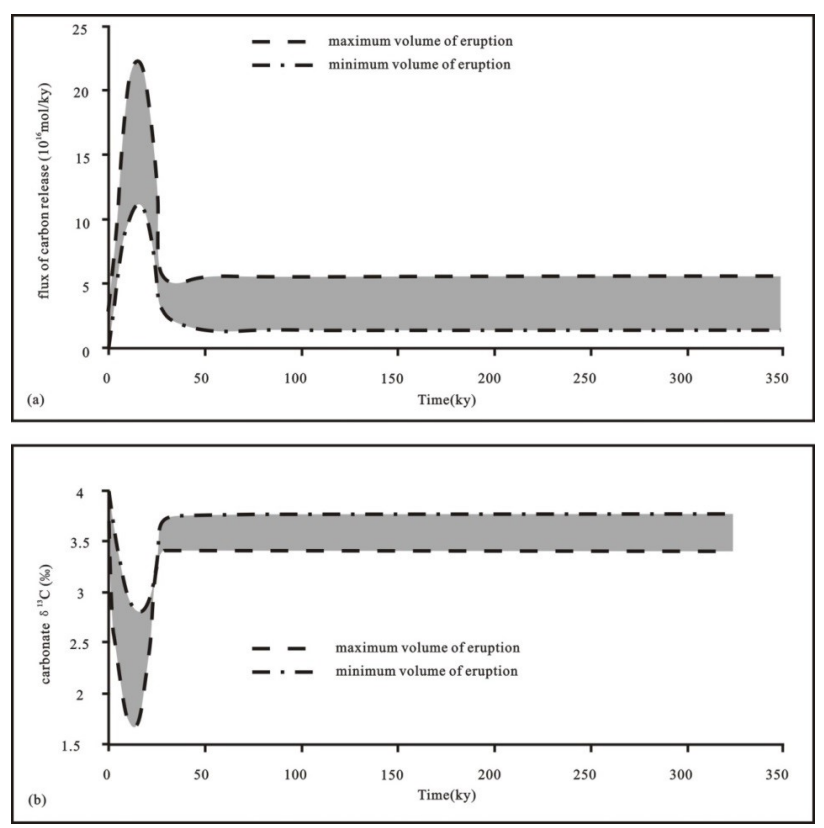

Figure 4: The figure shows the simulated carbon flux of volcanic eruption versus time (a) and the resulted carbon isotope varies with time (b).

tions to the reduction of inorganic $\delta^{13} \mathrm{C}$ are likely smaller. So, these volcanic events alone are not enough to lead to the multiple reduction amplitudes of carbon isotope in the early Triassic. One thing that should be noted is that volcanic activity causes a series of other secondary environmental changes. For example, the tectonic movement caused by volcanic activity allows original organic carbon to be exposed and weathered. Moreover, the release of $\mathrm{CO}_{2}$ and the warming effect this causes leads to the discharging of natural gas hydrate during a volcanic eruption. Hence, the comprehensive effects of these events should be considered integrally.

\subsection{Release of methane hydrate (RMH)}

Previous scholars have mentioned the release of methane hydrate at the Permian-Triassic boundary, and interpreted the negative excursion of $\delta^{13} \mathrm{C}$ in this period based on this event [16]. The release of methane hydrate causes the negative excursion of inorganic $\delta^{13} \mathrm{C}$ due to the very low $\delta^{13} \mathrm{C}$ value of biogenic methane. According to Alexei and Milkov[32], the carbon isotope composition of methane in hydrates lies between $-74.7 \% \mathrm{ffl}$ and $-41.9 \% \mathrm{ffl}$. When this methane is released from undersea hydrates, a huge amount of $\mathrm{CO}_{2}$, which is extremely enriched in light carbon enters the atmospheric-ocean system.

The volume of undersea material capable of storing natural gas hydrates is estimated to be $1 \times 10^{6} \sim 6 \times 10^{6} \mathrm{~km}^{3}$. As an average, only $1-10 \%$ of the total volume of material contains natural gas hydrates at present. Thus, it can be calculated that there is about $1000 \sim 22000 \mathrm{Gt}\left(\mathrm{Gt}=10^{15} \mathrm{~g}\right)$ of carbon stored in these natural gas hydrates(see the detailed demonstration of approximation in reference [33]). When this part of methane is released and enters the exogenous cycle system, it will be oxidized into $\mathrm{CO}_{2}$ extremely enriched in light carbon [34]. During the simulation, the process of the methane getting oxidized into $\mathrm{CO}_{2}$ is instantaneous (Reaction 1):

$$
\left.{ }^{12} \mathrm{CH}_{4}+2 \mathrm{O}_{2} \rightarrow 2 \mathrm{H}_{2} \mathrm{O}+{ }^{12} \mathrm{CO}_{2} \text { (Reaction } 1\right) .
$$

Therefore, this event can lead to the reduction of carbon isotope in exogenous carbonreserves very quickly. During the simulation, the carbon isotope composition of $\mathrm{CH}_{4}$ in natural gas hydrates is set as $-60 \%$ ffl. If $50 \%$ of the current reserve volume releases into free $\mathrm{CH}_{4}$ within $300 \mathrm{kyr}$ and $100 \%$ of free $\mathrm{CH}_{4}$ entering surface seawater and air gets oxidized instantly, the average flux entering the exogenous carbon cycle system should be $0.21 \sim 4.58 \times 10^{15} \mathrm{~mol} \mathrm{C} / \mathrm{kyr}$.

According to the simulation results, if a half of the maximum current natural gas hydrate reserve is released within 100 500 kyr, the $\delta^{13} \mathrm{C}$ value reduces $12 \% \mathrm{ffl} \sim 2.4 \% \mathrm{ffl}$ (Fig. 5). In these results, the maximum value is higher than the maximum drop of carbon isotope previously reported in the early Triassic (about 10\% ffl). For a reduction of 6\% ffl within $300 \mathrm{kyr}, 1780 \mathrm{Gt}$ carbon is required, which is very close to the upper limit of the current natural gas hydrate reserve but still lies in the reasonable region. Hence, the release of methane hydrate is a convincing explanation for the negative excursion of a single carbon isotope.

It is widely recognized that the release of methane is one of the major causes for the reduction of carbon isotope during the Paleocene-Eocene Thermal Maximum event (PETM)[26]. However, more than 10000 Gt carbon releasing from $\mathrm{CH}_{4}$ is required for the reduction of $10 \% \mathrm{ffl}$ 


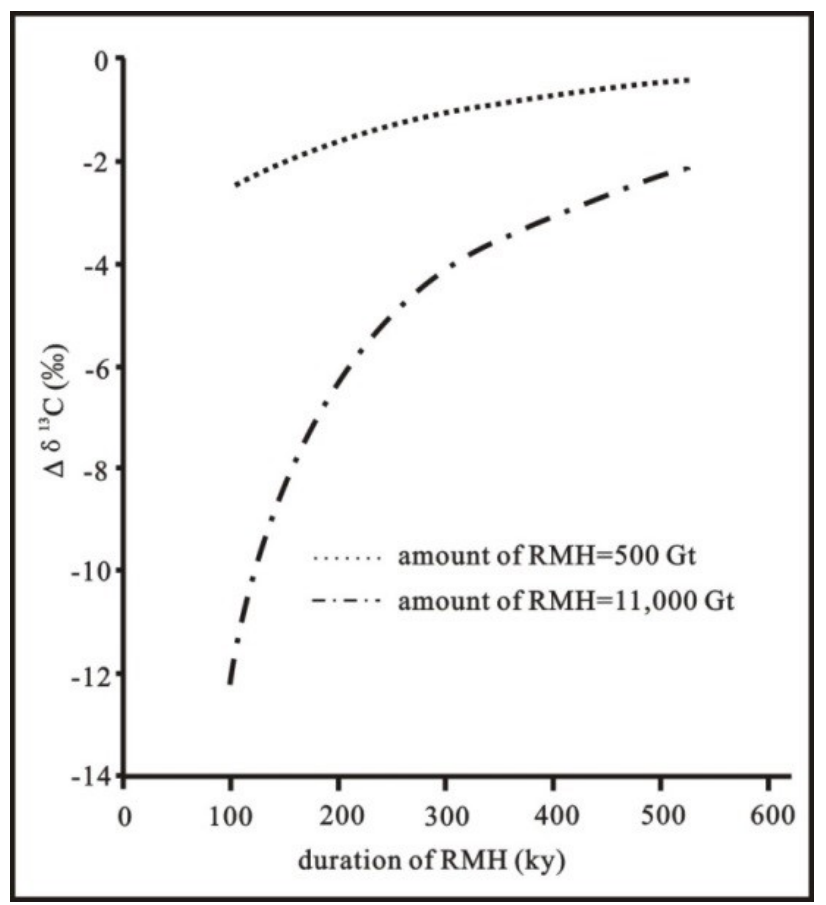

Figure 5: Simulation of inorganic carbon isotope fluctuation caused by the release of methane $\left(\mathrm{CH}_{4}\right)$ in natural gas hydrates versus duration time, the pecked line stands for the upper limit of total release amount, the dotted line refers to the lower limit of total release amount, and the vertical coordinate denotes the introduced inorganic carbon isotope variation amount.

within $100 \mathrm{kyr}$, which is several times higher than the carbon amount estimated to explain the carbon isotope reduction of PETM within 300 kyr [26]. Different from the Paleocene-Eocene Thermal Maximum, the carbon isotope fluctuation within much longer time periods occurred after the negative excursion of $\delta^{13} \mathrm{C}$ at the Permian-Triassic boundary. Assuming that the sedimentation rate is constant, it is still difficult to explain the significantly negative excursion within periods longer than $300 \mathrm{kyr}$. This is because the increase of duration of isotope excursion will lead to the increase of methane released during the same excursion. As displayed in Fig. 5, $11000 \mathrm{Gt}$ methane released within $300 \mathrm{kyr}$ only has an influence of $-4 \% \mathrm{ffl}$ on $\delta^{13} \mathrm{C}$, which is even smaller if given the longer releasing duration time. Moreover, the frequent reduction and increase of $\delta^{13} \mathrm{C}$ in the early Triassic requires the interactive storage and release of methane hydrates. At the same time, methane hydrates in sediments are the biogenic methane library, which is vividly compared to the condenser of the carbon cycle by Dickens [26]. According to this opinion, the methane hydrate must experience recharging before it isable to discharge again. The charging process takes place during methanogenesis, which proceeds very slowly [35] and limits the fast supply to the methane hydrate reserving layer. Hence, the $\delta^{13} \mathrm{C}$ record of the whole early Triassic cannot be explained by the methane driving theory. Moreover, compared to volcanic activities, the assumptions of methane hydrate release still demand necessary sedimentation evidence.

\subsection{Variation of organic carbon burial rate (fbg)}

The carbon isotope composition of marine carbonate reveals the dynamic equilibrium between marine carbonate storage and organic carbon burial. Hence, unless sudden geological events take place, the massive variation of the burial rates of organic carbon and inorganic carbon is also a possible explanation of the positive/negative excursion of the carbon isotope. The carbon isotope composition of biological carbon reserves is comparably light, the sudden burial of which unavoidably leads to the decrease of light carbon in the whole exogenous carbon cycle system and the carbon isotope composition experiences positive excursion. At the Permian-Triassic boundary, the ecosystem encountered paroxysmal cataclysm events. The massive extinction of terrestrial vegetation [36] reduced the stability of soil, thus, leading to the decaying of plants and weathering of soil. All these factors result in light $\mathrm{CO}_{2}$ being quickly released into the atmosphere and the value of $\delta^{13} \mathrm{C}$ decreasing [37].

Both the ocean and land are primary preservation systems of organic carbon. The late Paleozoic era is a largescale coal forming period in the Phanerozoiceon and also the period with the highest organic carbon burial rate [38]. Geological events, including coal-forming interruption in the early Triassic, indicate that the collapse of productivity leads to the massive shrinkage of the organic matter storage system. Accordingly, the oxidation amount of organic carbon increases while the burial flux reduces significantly. Berner [39] reported that the organic carbon burial flux in the late Paleozoic era, which was higher than the current value, rapidly decreased to that at the PermianTriassic boundary, which was far lower than the current value (Fig. 6). Hence, in this study, symbol ' $f$ ' is used to denote the percentage of carbon flux of organic carbon sink $\mathrm{F}_{\text {borg }}$ to the whole flux of carbon sink $\mathrm{F}_{\text {out }} . \Delta_{B}$ is adopted to represent the deviation between the carbon isotope of sedimentary organic carbon and the carbon isotope of sedimentary inorganic carbon, i.e.:

$$
\begin{aligned}
f_{\text {org }}=F_{\text {borg }} / F_{\text {out }} & =F_{\text {borg }} /\left(F_{\text {borg }}+F_{\text {bcarb }}\right) \\
\delta_{\text {borg }} & =\delta_{\text {carb }}+\Delta_{B}
\end{aligned}
$$




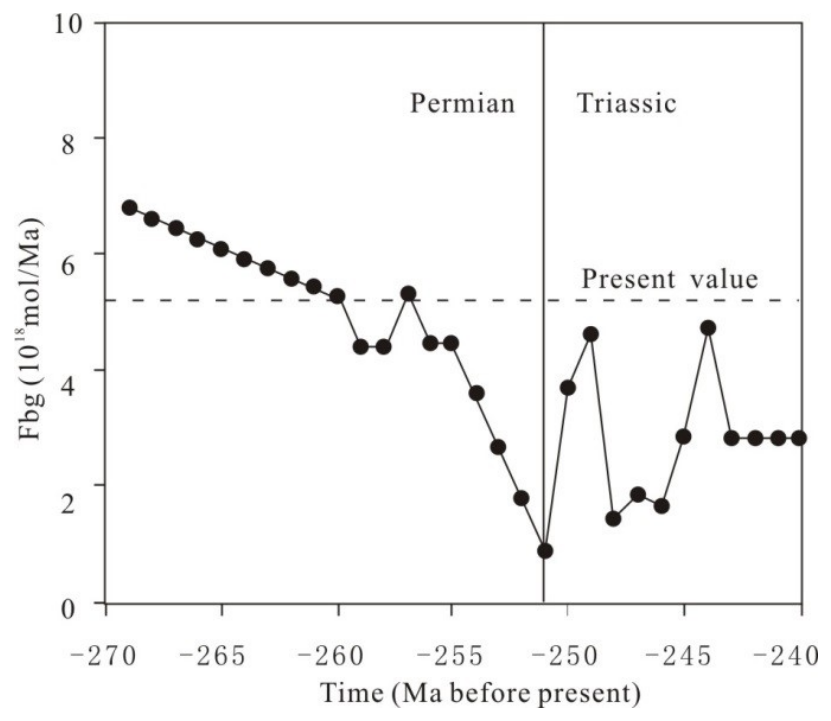

Figure 6: Pitch point figure of organic carbon burial flux (Fbg) and time (after Berner [39])

According to the above discussion, the relationship between the organic carbon burial fraction and the corresponding carbon isotope variation can be obtained. Available studies have proved that the organic carbon burial flux of terrestrial ecosystem is equal to that of the marine ecosystem [40]. Hence, during the simulation, the organic carbon burial amount of the terrestrial ecosystemwas initially set as 50\% of the whole organic carbon burial amount. The initial value of $\mathrm{f}_{\text {org }}$ is set as 0.2 according to Fig.1 while that of $\Delta_{B}$ is set as $30 \% \mathrm{ffl}$. The results proved that if other conditions are maintained, a 10\% reduction of the organic carbon burial fraction will lead to $1.95 \%$ reduction of $\delta^{13} \mathrm{C}$ value. Therefore, an individual terrestrial ecosystem crisis is not likely to cause the $\delta^{13} \mathrm{C}$ negative excursion record found at the Permian-Triassic boundary. However, the collapse of the terrestrial ecosystem will lead to the exposure and weathering of buried organic carbon. The total carbon amount of all terrestrial vegetation and soil is around $2000 \mathrm{Gt}$, which can produce a $\delta^{13} \mathrm{C}$ negative shift of $1.2 \% \mathrm{ffl}$. Hence, this part should be taken into consideration when discussing the influence of the terrestrial ecosystem crisis on the inorganic carbon isotope.

Also, the variation of marine carbonate $\delta^{13} \mathrm{C}$ isotope is related to not only the dynamic balance between organic carbon and inorganic carbon, but also to the total amount of dissolved inorganic carbon (DIC) in the ocean reservoir. The greater the total carbon amount, the stronger the buffer ability of ocean will be. This difference of buffer stability can be found in the simulated result (Fig. 7). Since the salinity of carbonate in the early Triassic is relatively high, the resistance of the early Triassic to the carbon cycle variation is supposed to be strong, considering from the aspect of seawater itself. This also reveals that the intense degree of carbon cycle fluctuation is much more substantial than we have observed.

If the variation of organic carbon burial fraction is the major cause of the massive fluctuation of $\delta^{13} \mathrm{C}$ in the early Triassic, very high organic carbon storage and very low organic carbon storage appear alternately for many cycles in the early Triassic, especially since the variation of $\mathrm{f}_{\text {org }}$ between 0.1 and 0.3 only generates a $\delta^{13} \mathrm{C}$ excursion of about $3.8 \% \mathrm{ffl}$ (Fig. 7).It should be noted that the repetitive shift features of the early Triassic isotope record are very similar to those of the Neoproterozoic and Cambrian, revealing that they may have a similar driving mechanism. Scholars have proposed an assumption to explain the ultra-high $\delta^{13} \mathrm{C}$ value in that time. That is, under the anoxic conditions of tropical river deltas, the increase of phosphate circulation inputs more nutrients and leads to an increase in the rate of organic carbon burial [41]. If this assumption is reasonable, the conditions in the early Triassic arelikely to be the same. Therefore, the alternative variation between the oxidizing condition and the anoxic condition is possible to have existed in the Tethys area and results in the significant variation of organic carbon burial rate.

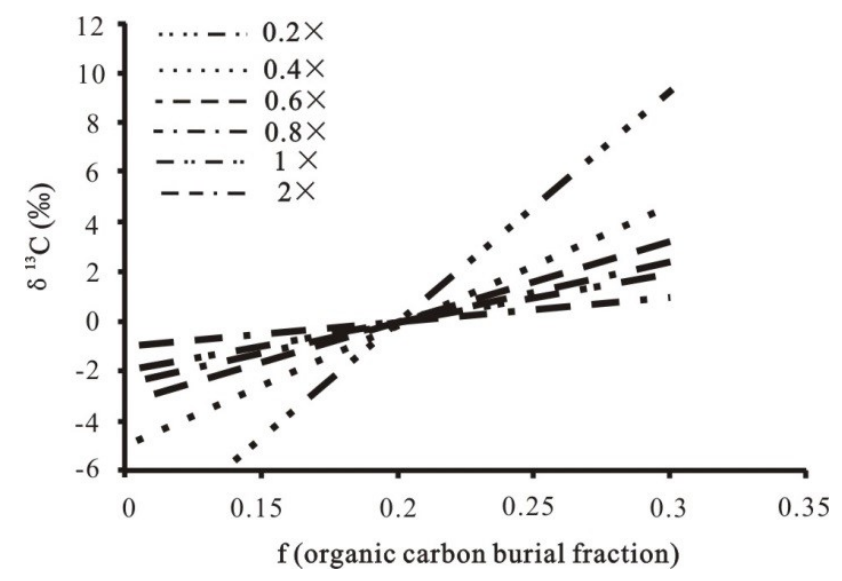

Figure 7: The relationship between the carbon isotope variation and organic carbon burial fraction $f$ under the conditions with different sized ocean DIC reservoirs (numbers inlegend represent the ratio multiplied by the amount of ocean DIC reservoir shown in Fig. 1). 


\subsection{Variation of primary productivity in the ocean surface}

Some researchers have attributed the negative excursion of organic carbon isotope at the Permian-Triassic boundary to the variation of primary productivity at the sea surface e.g., [42, 43], since sea surface bionts preferentially utilize light carbon during photosynthesis. If these bionts disappear and the primary productivity is reduced, this part of light carbon will enter into the ocean and lead to the reduction of inorganic and organic carbon isotope composition in undersea sediments. Regarding this mechanism, the extinction or prosperity of primary productivity has a great influence on carbon isotope ratios. However, whether the massive extinction event in the late Permian led to an increase or decrease of ocean primary productivity remains controversial. Some scholars suggest that the productivity of the ocean surface decreased dramatically after the mass extinction $[44,45]$. Meanwhile, other researchers declared that the inundation of autotropic microorganisms which is represented by cyanobacteria made significant contributions to the primary productivity of the ocean. Specifically, the primary productivity of the ocean surface at the Permian-Triassic boundary did not reduce significantly with the disappearance of macro and a part of the micro palaeobios [46-48]; it may have even experienced an improvement in primary productivity [49]. Also, the matching relationship between the starting points of biological extinction and the carbon isotope fluctuation is still not clear. One thing that can be confirmed is that, if the inorganic $\delta^{13} \mathrm{C}$ value experienced a negative excursion before the massive extinction, this part of the negative shift has nothing to do with the reduction of ocean primary productivity.

According to the latest research results mentioned above, the authors believe that the massive extinction does not necessarily lead to the significant reduction of ocean primary productivity, i.e., it is not strong enough to cause the negative excursion of inorganic carbon isotope at the Permian-Triassic boundary. However, as a mechanism that disturbs the original carbon cycle system, it provides a possible explanation for the repetitive occurrence of high $\delta^{13} \mathrm{C}$ values in the early Triassic. Moreover, recent work has demonstrated that terrigenous weathering transports a large amount of phosphate into the ocean, resulting in the spread of microorganisms, $[46,50,51]$. The increase of phosphate concentration leads to the improvement of ocean surface primary productivity and thereby accelerates the burial rate of organic carbon.

\section{Discussion}

To sum up, this work suggests that individual events (volcanic activity, the collapse of terrestrial ecosystem, etc.) are not strong enough to cause the negative carbon isotope excursion at the Permian-Triassic boundary. The causal relationships between events reflect the possible existence of superimposed influences on the $\delta^{13} \mathrm{C}$ value of marine carbonate. For example, volcanic activity produces massive amounts of $\mathrm{CO}_{2}$, which accelerates the oxidation of organic matter, while the collapse of the terrestrial ecosystem synchronously affects the weathering degree and burial amount of original organic carbon. From this perspective, all of these events are still possible important causes of the carbon isotope negative excursion. The repetitive and substantial fluctuation of carbon isotope in the early Triassic can be possibly attributed to the disturbed dynamic balance between inorganic carbon reserves and organic carbon reserves. The extinction of ocean marine organisms may not lead to the reduction of primary productivity. Thus, the reduction of organic carbon reserve at the boundary line is mainly caused by the collapse of the terrestrial ecosystem. The repetitive occurrence of a $\delta^{13} \mathrm{C}$ positive shift in the early Triassic is supposed to be relatedto the increase of primary productivity and organic carbon burial amount caused by flourishing microorganisms.

The massive biological extinction at the PermianTriassic boundary is marked by the vast disappearance of marine epigenetic organisms (macroorganisms and a few microorganisms). Many researchers declared that the negative carbon isotope excursion at the Permian-Triassic boundary was mainly caused by the massive biological extinction. However, there still has not been a conclusion about the relationship between the starting point of biological extinction and the beginning of the carbon isotope fluctuation. Even successive work can prove that the minimum value of carbon isotope around the boundary line occurs below the main extinctionline; it still cannot be proved whether the rapid disappearance of macroorganisms would lead to the reduction of primary productivity and a negative carbon isotope excursion. For example, the massive biological extinction in the later Devonian corresponds to the sedimentation of black shale and the positive shift of carbon isotope [52, 53]. Hence, we are more likely to consider abnormal environmental events as the major cause of the negative carbon isotope excursion. The repetitive occurrence of a positive inorganic carbon isotope excursion in the Tethys area possibly indicates the further improvement of productivity after the mass extinction at the Permian-Triassic boundary. This is related to the 
significant increase of phosphate transport flux [22] and is in agreement with the stratified/anoxia ocean. It is also indicated that when these abnormal environmental events end or weaken, the recovery of organisms has already begun. If many new species only appear in the late Early Triassic epoch or the early Middle Triassic epoch, the increase of biological productivity may originate from the recovery of survival bionts instead of the origination of new species. If successive work can prove that the isotope variation in the early Triassic epoch is global, then the black shale frequently appearing in Triassic ocean sediments is very likely an important carbon sink [54].

\section{Conclusions}

The influences of related geological events on the carbon cycle process at the transient stage between the Permian and Triassic were quantitatively simulated based on the GEOCARB model. The results proved that individual events (such as volcanic activities, the collapse of terrestrial ecosystem and others) are not strong enough to cause the negative excursion of carbon isotope in the early Triassic. Instead, the superimposed effect of multiple events possibly exists. Even the release of methane hydrate can lead to the negative shift of inorganic carbon, but it is unable to result in the repetitive and substantial fluctuations of carbon isotope in the whole early Triassic. These fluctuations can be attributed to the interrupted balance between inorganic carbon reserves and organic carbon reserves. The extinction of ocean biontsdoes not necessarily cause the decrease of primary productivity. Thus, the reduction of organic carbon reserve at the Permian-Triassic boundary is mainly caused by the collapse of the terrestrial ecosystem. The multiple positive excursions of $\delta^{13} \mathrm{C}$ are likely related to the improvement of primary productivity and the increase of organic carbon burial rate resulting in from the prosperity of microorganisms.

Acknowledgement: This study was supported by the National Natural Science Foundation of China (41402104,41602118) and The Young and Middle-aged Key Teachers project of Chengdu University of Technology (KYGG201719). We deeply acknowledge the two anonymous reviewers for their critical comments and advice that significantly improved our manuscript.

\section{References}

[1] Veizer J., Ala, D., Azmy, K., Bruchschen, P., Buhl, D., ${ }^{87} \mathrm{Sr} /{ }^{86} \mathrm{Sr}$, $\delta^{13} \mathrm{C}$ and $\delta^{18} \mathrm{O}$ evolution of Phanerozoic seawater. Chem. Geol., 1999, 161: 59-88.

[2] Huang S. J., Carbon isotopes of Permian and Permian-Triassic boundary in Upper Yangtze platform and the mass extinction. Geochimica, 1994, 23, 60-67 (in Chinese with English abstract).

[3] Huang S. J., Huang K. K., Lv J., Lan Y. F., Carbon isotopic composition of Early Triassic marine carbonates, Eastern Sichuan Basin, China.Sci. China: Earth Sci, 2012, 55, 2026-2038.

[4] Li Y. C., Gradual and abrupt shifts in carbon isotope of limestones during Permian-Triassic transitional period in South China.Geochimica, 1999, 28, 351-358 (in Chinese with English abstract).

[5] Payne J. L., Lehrmann D. J., Wei J. Y., Orchard M. J., Schrag D. P., Knoll A. H., Large perturbations of the carbon cycle during recovery from the end-Permian extinction. Science, 2004, 305, 506-509.

[6] Magaritz M., Bart R., Baud A., Holser, W. T., The carbon-isotope shift at the Permian-Triassic boundary in the southern Alps is gradual.Nature, 1988, 331, 337-339.

[7] Holser W. T.,Schönlaub, H. P. T., The Permian-Triassic boundary in the Carnic Alps of Austria (Gartnerkofel region). Abhandlungen Geologische Bundesanstalt Autriche, 1991, 45, 232.

[8] Holser W. T.,Magaritz M., Cretaceous/Tertiary and Permian/Triassic boundary events compared. Geochim.Cosmochim.Acta, 1992,56, 3297-3309.

[9] Heydari E., Hassanzadeh J., Wade W. J., Ghazi, A. M., PermianTriassic boundary interval in the Abadeh section of Iran with implications for mass extinction: Part 1-Sedimentology. Palaeogeogr., Palaeoclimatol., Palaeoecol., 2003, 193, 405-423.

[10] Kamo S. L., Czamanske G. K., Amelin Y., Fedorenko V. A., Davis D. W., Trofimov, V. R., Rapid eruption of Siberian flood-volcanic rocks and evidence for coincidence with the Permian-Triassic boundary and mass extinction at $251 \mathrm{Ma}$, Earth Planet.Sci.Lett., 2003, 214, 75-91.

[11] Basu A. R., Poreda R. J., Renne P. R.,Teichmann F. Vasiliev Y. R., Sobolev N. V.,Turrin, B. D., High-He-3 plume origin and temporal-spatial evolution of the Siberian flood basalts. Science, 1995, 269, 822-825.

[12] Renne P. R.,Basu A. R., Rapid eruption of the Siberian traps flood basalts at the Permo-Triassic boundary. Science, 1991, 253, 176179.

[13] Wignall P. B., Hallam, A., Anoxia as a cause of the Permian Triassic mass extinction - evidence from Northern Italy and the Western United-States. Palaeogeogr., Palaeoclimatol., Palaeoecol., 1992, 93, 21-46.

[14] Kato Y., Nakao K.,Isozaki, Y., Geochemistry of Late Permian to Early Triassic pelagic cherts from Southwest Japan; implications for an oceanic redox change. Chem. Geol., 2002, 182,1534.

[15] Knoll A. H., Bambach R. K., Canfield D E.,Grotzinger, J. P., Comparative Earth history and Late Permian mass extinction. Science, 1996, 273, 452-457.

[16] Krull E. S., Retallack G. J., Campbell I H., Lyon G. L., $\delta^{13}$ Corg chemostratigraphy of the Permian-Triassic boundary in the Maitai Group, New Zealand: evidence for high-latitudinal methane release. N.Z.J. Geol. Geophys., 2000, 43, 21-32. 
[17] Veizer J., Hoefs J., The nature of $0^{18} / 0^{16}$ and $\mathrm{C}^{13} / \mathrm{C}^{12}$ secular trends in sedimentary carbonate rocks. Geochim. Cosmochim. Acta, 1976, 40, 1387-1395.

[18] Garrels R. M.,Lerman, A., Phanerozoic cycles of sedimentary carbon and sulfur. Proc. Natl. Acad. Sci. U.S.A., 1981, 78, 46524656.

[19] Holser W. T., Gradual and abrupt shifts in ocean chemistry during Phanerozoic time. In: Holland, H.D., Trendall, A.F. (Eds.), Patterns of Change in Earth Evolution. Springer, Berlin, pp. 1984, 123-143.

[20] Kump L. R., Garrels, R. M., Modeling atmospheric $\mathrm{O}_{2}$ in the global sedimentary redox cycle. Am. J. Sci., 1986, 286, 337-360.

[21] Berner R. A., Kothavala, Z., GEOCARB III: a revised model of atmospheric $\mathrm{CO}_{2}$ over Phanerozoic time, Am. J. Sci., 2001, 301, 182-204.

[22] Kump L. R.,Arthur, M. A., Interpreting carbon-isotope excursions Carbonate and organic matter. Chem. Geol., 1999,6, 181198.

[23] Formolo M. J., Lyons T. W., Zhang C., Kelley C., Sassen R., Horita J., Cole, D. R., Quantifying carbon sources in the formation of authigenic carbonates at gas hydrate sites in the Gulf of Mexico. Chem. Geol., 2004, 205, 239-251.

[24] Hayes J. M., Strauss H., Kaufman, A. J., The abundance of in marine organic matter and isotopic fractionation in the global biogeochemical cycle of carbon during the past $800 \mathrm{Ma}$. Chem.Geol., 1999,161, 103-125.

[25] Sun Y. D., JoachimskiM. M., Wignall P. B., Yan C. B., Chen Y. L., Jiang H. S., Wang L. N., Lai, X. L., Lethally hot temperatures during the Early Triassic greenhouse. Science, 2012, 388, 366-370.

[26] Dickens G. R., Rethinking the global carbon cycle with a large,dynamic and microbially mediated gas hydrate capacitor. Earth Planet. Sci. Lett., 2003,213, 169-183.

[27] Korte C., Pande P, Kalia P., Kozur J. W., Joachimski M. M.,Oberbänsli, H., Massive volcanism at the Permian-Triassic boundary and its impact on the isotopic composition of the ocean and atmosphere. J. Asian Earth Sci., 2010, 37, 293-311.

[28] Bachmann G. H., Kozur H. W., The Germanic Triassic: correlations with the international scale, numerical ages and Milankovitch cyclicity. Hallesches Jahrbuchfür Geowissenschaften, 2004, B26, 17-62.

[29] Kakuwa Y., Matsumoto R., Cerium negative anomaly just before the Permian and Triassic boundary event-the upward expansion of anoxia in the water column. Palaeogeogr., Palaeoclimatol., Palaeoecol., 2006, 229, 335-344.

[30] Kozur H. W., Biostratigraphy and event stratigraphy in Iran around the Permian-Triassic boundary (PTB): implications for the causes of the PTB biotic crisis.Glob.Planet. Change, 2007, 55, 155-176.

[31] Cao C. Q., Wang W., Jin, Y. G., The anomaly of carbon isotopic of marine strata across the Permian-Triassic boundary in South China, in Rong I Y, Fang Z J (Eds), Mass extinction and recoveryEvidence from the Palaeozonic and Triassic of South China. University of Science and Technology of China Press, Hefei, pp, 2004, $773-784$ (in Chinese).

[32] Alexei V., Milkov A. V., Molecular and stable isotope compositions of natural gas hydrates: A revised global dataset and basic interpretations in the context of geological settings. Organ. Geochem., 2005, 36, 681-702.

[33] Dickens G. R., The potential volume of oceanic methane hydrates with variable external conditions. Organ. Geochem.,
2001, 32, 1132-1193.

[34] Wuebbles D. J.,Hayhoe, K., Atmospheric methane and global change, Earth Sci. Rev., 2002, 57, 177-210.

[35] Zachos J., Pagani M., Sloan L., Thomas E., Billups, K., Trends, rhythms, and aberrations in global climate $65 \mathrm{Ma}$ to present, Science, 2001, 292, 686-693.

[36] Eshet Y., Rampino M. R.,Visscher H., Fungal event and palynological record of ecological crisis and recovery across the Permian-Triassic boundary. Geology, 1995,23, 967-970.

[37] Sephton M. A., Looy C. V., Brinkhuis H.,Wignall P. B., De Leeum J. W.,Visscher, H., Catastrophic soil erosion during the endPermian biotic crisis. Geology, 2005, 33, 941-944.

[38] Berner R. A., A new look at the long-term carbon cycle. GSA Today, 1999, 9, 1-6.

[39] Berner R. A., The carbon and sulfur cycles and atmospheric oxygen from Middle Permian to Middle Triassic. Geochim. Cosmochim. Acta, 2005, 69, 3211-3217.

[40] Berner R. A., The long-term carbon cycle, fossil fuels and atmospheric composition. Nature, 2003, 426, 323-326.

[41] Schrag D. P., Berner R. A., Hoffman P. F., Halverson, G. P., Geochem. Geophys. Geosyst., 2002, 3, 10.

[42] Wang K., Geldsetzer H. H. J., Krouse H. R., Permian-Triassic extinction: Organic evidence from British Columbia, Canada. Geology, 1994, 22, 580-584.

[43] Algeo T.J., Henderson C.M., Tong J.N., Feng Q.L., Yin H.F., Tyson R. V., Plankton and productivity during the PermianTriassic boundary crisis: An analysis of organic carbon fluxes. Glob.Planet. Change, 2013, 105, 52-67.

[44] Rampino M. R., Caldeira K., Major perturbation of ocean chemistry and a "Strangelove Ocean" after the end-Permian mass extinction. Term Nova, 2005, 17, 554-559.

[45] Cao C. Q., Love G. D., Hays L. E., Wang W., Shen S. Z., Summons R. E., Biogeochemical evidence for euxinic oceans and ecological disturbance presaging the end-Permian mass extinction event.Earth Planet. Sci. Lett., 2009, 281, 188-201.

[46] Xie S. C., Pancost R. D., Wang Y. B., Hao Y., Wignall P. D., Liu G. M., Jia C. L., Chen L., Cyanobacterial blooms tied to volcanism during the 5-million-year Permo-Triassic biotic crisis. Geology, 2010, 38, 447-450.

[47] Algeo T. J., Hinnoy L., Moser J., Maynard J. B., Elswick E., Kuwahara K., Sano H., Changes in productivity and redox conditions in the Panthalassic Ocean during the latest Permian. Geology, 2010, 38, 187-190.

[48] Wignall P. B., Bond D. P. G., Kuwahara K., Kakuwa Y., Newton R. J.,Poulton S. W., An 80 million year oceanic redox history from Permian to Jurassic pelagic sediments of the Mino-Tamba terrane, SW Japan, and the origin of four mass extinctions. Glob. Planet. Change, 2010, 71, 109-123.

[49] Luo G. M., Microbial geological processes and the associated biogeochemical cycles of carbon, nitrogen and sulfur during the Permian-Triassic crisis interval. PHD dissertation, China University of Geosciences, Wuhan, 2011 (in Chinese).

[50] Sedlacek A.R., Saltzman M.R., Algeo T.J., Horacek M., Brandner R., Foland K., Denniston, R.F., ${ }^{87} \mathrm{Sr} /{ }^{86} \mathrm{Sr}$ stratigraphy from the Early Triassic of Zal, Iran: linking temperature to weathering rates and the tempo of ecosystem recovery. Geology, 2014, 42, 779-782.

[51] Lau K. V.,Altiner D., Kelley B. M., Kump L. R., Lehrmann D. J., Silva-Tamayoe J. C., Weaver K. L., Yu M., Payne, J. L., Marine anoxia and delayed Earth system recovery after end-Permian 
extinction. Proc. Natl. Acad. Sci. U.S.A., 2016, 113, 2360-2365.

[52] Joachimski M. M., Ostertag-Henning C., Pancost R. D., Strauss H., Freeman K. H., Littke R. Damsté J. S. S., Racki G., Water column anoxia, enhanced productivity and concomitant changes in carbon isotope and sulfur isotope across the FrasnianFamennian boundary. Chem. Geol., 2001, 175, 109-131.
[53] Joachimski M. M., Pancost R. D., Freeman K. H., OstertayHenning C., Buggisch, W., Carbon isotope geochemistry of the Frasnian-Famennian transition. Palaeogeogr. Palaeoclimatol. Palaeoecol., 2002, 181, 91-109.

[54] Suzuki N., Ishida K., Shinomiya Y., Ishiga H., High productivity in the earliest Triassic ocean: black shales, Southwest Japan. Palaeogeogr. Palaeoclimatol. Palaeoecol., 1998, 141, 53-65. 